\title{
Perbedaan motivasi kerja tutor pendidikan nonformal ditinjau dari status pekerjaan di Provinsi Bali
}

\author{
Putu Dina Yuniarini dan Naomi Vembriati \\ Program Studi Sarjana Psikologi, Fakultas Kedokteran, Universitas Udayana \\ naomi.vembriati@unud.ac.id
}

\begin{abstract}
Abstrak
Tingginya angka putus sekolah mendorong pemerintah membentuk alternatif Tingginya angka putus sekolah mendorong pemerintah membentuk alternatif pilihan jenjang pendidikan yaitu pendidikan nonformal. Salah satu lembaga pendidikan nonformal adalah Pendidikan Kesetaraan yang berada di bawah Pusat Kegiatan Belajar Masyarakat (PKBM). Pendidik di pendidikan nonformal disebut dengan tutor. Dilihat dari status pekerjaan tutor, dapat dibedakan menjadi dua yaitu tutor murni dan tutor dengan pekerjaan tambahan. Tutor murni adalah tutor yang kesehariaanya bekerja hanya di lembaga pendidikan non formal. Tutor dengan pekerjaan tambahan bekerja selain menjadi seorang tutor juga memiliki pekerjaan tambahan selain menjadi tutor contohnya mengajar les atau menjadi guru honor di pendidikan formal. Penelitian ini bertujuan untuk melihat perbedaan motivasi kerja tutor pendidikan nonformal ditinjau dari status pekerjaannya di Provinsi Bali. Subjek dalam penelitian ini sejumlah 322 orang yang terdiri dari 157 tutor murni dan 165 tutor dengan pekerjaan tambahan. Teknik Sampling dalam penelitian non random sampling dengan menggunakan sampel jenuh. Instrumen dalam penelitian ini menggunakan skala motivasi kerja sebanyak 60 item $(\alpha=0,845)$. Hasil uji hipotesis menggunakan independent sample t-test nilai signifikansi motivasi internal sebesar 0,662 dan motivasi eksternal 0,889 $(\mathrm{p}<0,05)$, maka tidak terdapat perbedaan antara motivasi kerja ditinjau dari status pekerjaannya
\end{abstract}

Kata kunci : Motivasi kerja, status pekerjaan, tutor pendidikan nonformal.

\begin{abstract}
The high dropout rates have caused the government to try to provide alternative options of education as non-formal education. One of the non-formal education is Equality Education under the Community Learning Activity Center (PKBM). Educator in non-formal education is called a Tutor. Seeing the status of the Tutor's work, there is indeed a pure tutor and the ones with other additional work. A pure tutor is a tutor who does the daily work only at non-formal education institutions. While tutors with additional work is the one who work as a tutor at the non-formal education and also has additional job such as private teacher or as honorarium teacher in the formal education. This study aims to see the difference in the work motivation of the non-formal education tutor in terms of employment status in Bali Province. Subjects of the study are 322 respondents of 157 pure tutors and 165 tutors with additional jobs. Non Random sampling were used by using Saturation Sample. This study using 60 items of work motivation scale $(\alpha=0.845)$. Hypothesis test using independent sample t-test internal resulting motivation significant of 0.662 and external motivation of 0.889 (p $<0.05$ ), There is no difference between work motivation viewed from the job status.
\end{abstract}

Keywords : Job status, non-formal education tutor, work motivation. 


\section{LATAR BELAKANG}

Di Indonesia sistem pendidikan nasional dilaksanakan melalui tiga jalur yaitu jalur formal, informal, dan nonformal. Pendidikan formal adalah jalur pendidikan terstruktur dan berjenjang yang terdiri dari pendidikan berstatus negeri dan berstatus swasta. Pendidikan formal terdiri dari pendidikan anak usia dini (PAUD), pendidikan dasar (Sekolah Dasar/SD), pendidikan menengah (Sekolah Menengah Pertama dan Sekolah Menengah Atas), dan pendidikan tinggi (Universitas) (Kamil, 2011). Pendidikan informal merupakan lingkungan pendidikan dalam keluarga dimana setiap orang mendapatkan pengembangan pribadi, sikap, dan tingkah laku pertama dan utama melalui proses interaksi yang berlangsung setiap harinya diantara sesama anggota keluarga (Senjawati, 2015). Pendidikan nonformal adalah pendidikan yang diselenggarakan di luar sistem pendidikan formal, yang sifatnya fleksibel dan sengaja diselenggarakan untuk mendukung pendidikan seumur hidup bagi masyarakat yang memerlukan layanan pendidikan yang berfungsi sebagai pengganti, penambah, dan/atau pelengkap pendidikan formal (Siswato, 2013).

Salah satu bentuk pendidikan nonformal adalah pendidikan kesetaraan yang ditujukan bagi seluruh masyarakat yang tidak dapat kesempatan untuk mengenyam pendidikan disekolah atau pendidikan formal. Berbagai faktor yang memengaruhi mengapa seseorang memilih pendidikan nonformal diantaranya karena faktor putus sekolah, faktor status ekonomi, faktor keluarga, faktor geografis, bahkan faktor untuk memenuhi kebutuhan kerja (Dirjen PAUD dan Dikmas, 2017).

Salah satu wadah di pendidikan nonformal adalah Pusat Kegiatan Belajar Masyarakat (PKBM). PKBM menjadi solusi alternatif bagi peserta didik yang mengalami putus sekolah baik karena masalah ekonomi, pergaulan, ataupun masalah lainnya. PKBM memiliki program-program yaitu Pendidikan Anak Usia Dini (PAUD) yang terdiri dari Kelompok Bermain, Satuan PAUD Sejenis, dan Taman Kanak-Kanak, Kursus dan Pelatihan Keterampilan, Keaksaraan Fungsional, Program Paket A setara SD, Program Paket B setara SMP, Program Paket C setara SMA dan seluruh program ini dibentuk dari oleh dan untuk masyarakat. (Sutisna, 2012).

Pada pelaksanaannya seorang pendidik berperan penting untuk mewujudkan tujuan pembelajaran, dan memberikan materi pembelajaran, selain itu pendidik dituntut untuk memberikan pengajaran yang baik kepada peserta didik sehingga peserta didik tidak hanya mengerti tentang materi yang disampaikan melainkan mereka mampu memahami serta mengaplikasikan di kehidupannya. Pendidikan nonformal di kesetaraan pendidik adalah seorang tutor yang menilai belajar peserta didik dan kegiatan pembelajaran peserta didik (Sardiman 2010).

Tutor adalah orang yang memberi pelajaran (membimbing) kepada seseorang atau sejumlah kecil siswa dalam pelajarannya. Tutor adalah orang yang membelajarkan atau orang yang memfasilitasi proses pembelajaran di kelompok belajar. Tutor pendidikan noformal adalah masyarakat yang bertugas merencanakan, melaksanakan, mengevaluasi proses pembelajaran pada program keaksaraan Fungsional (KF), Kejar Paket A,B dan C (Raharjo, 2005).

Tutor adalah guru yang mengajar di pendidikan non formal. Jenis tutor dapat dibedakan berdasarkan status pekerjaannya terdapat dua jenis yaitu tutor murni dan tutor dengan pekerjaan tambahan. Tutor murni adalah tutor yang memang kesehariaanya bekerja hanya di lembaga pendidikan non formal. Tutor dengan pekerjaan tambahan bekerja selain menjadi seorang tutor juga memiliki pekerjaan tambahan di luar dari menjadi tutor contohnya mengajar les atau menjadi guru honor di pendidikan formal (Suhendar, 2017).

Sebagian waktu tutor banyak dicurahkan untuk menggarap proses belajar mengajar dan berinteraksi dengan peserta didik. Terkait hal tersebut, seorang tutor perlu memahami peranannya dalam kegiatan kegiatan belajar mengajar, sebagai berikut : informator, organisator, motivator, director, inisiator, fasilitator, mediator, evaluator (Departemen Pendidikan Nasional, 2003). Berdasarkan data pokok pendidik (dapodik) tahun 2017, diketahui jumlah tutor PKBM sebanyak 387 orang tutor di Provinsi Bali. Jumlah tutor murni sebanyak 195 orang tutor dan 192 orang tutor dengan pekerjaan tambahan lainnya. Selama dua tahun terakhir seluruh tutor di Provinsi Bali yang ada di pendidikan nonformal membantu peserta didiknya pada saat proses belajar mengajar untuk persiapan Ujian Nasional sampai kelulusan. Kelulusan peserta didik di Bali dua tahun terakhir hampi 90\% (Dapodik, 2017).

Studi pendahuluan yang dilakukan oleh peneliti mengungkap bahwa seorang tutor murni memperoleh gaji berkisar Rp. 35.000,-/sekali mengajar. Jumlah gaji yang diperoleh dalam sebulan sebesar Rp. 140.000,-/bulan. Ada juga tutor murni yang tidak dibayar dan untuk tutor dengan pekerjaan tambahan memiliki gaji yang lebih besar dari pada tutor murni pada umumnya. Perbedaan penghasilan antara tutor murni dan tutor dengan pekerjaan tambahan diperkirakan akan memberikan perbedaan motivasi kerja dalam mengajar.

Menurut Nurfarhana (2016) menyatakan bahwa salah satu faktor memengaruhi motivasi kerja adalah penghasilan yang diperoleh. Hal ini juga sejalan dengan penelitian yang dilakukan oleh Syamra (2016) mengenai pengaruh kompensasi finansial dan motivasi kerja guru terhadap kinerja guru SMK Negeri Pariwisata di Kota Padang. Syamra menyebutkan bahwa terdapat pengaruh kompensasi finansial terhadap motivasi kerja guru. Sari (2016) menyatakan dalam penelitiannya mengenai pengaruh gaji dan motivasi terhadap kinerja guru pada SMA Swasta Bagan Sinembah, Rokan Hilir, Riau menyebutkan bahwa gaji memiliki pengaruh yang signifikan terhadap motivasi kerja guru. Hal ini berarti bahwa apabila terdapat peningkatan gaji maka akan diikuti oleh peningkatan motivasi kerja guru.

Menurut Aamodt (2010) teori motivasi Herzberg disebut teori dua faktor yang dapat dibagi menjadi Hygiene Factors dan Motivation. Hygiene factors (faktor kesehatan) adalah faktor pekerjaan yang penting untuk adanya motivasi di tempat kerja. Hygiene factors adalah gambaran kebutuhan fisiologis individu yang diharapkan untuk dipenuhi. Hygiene Factors 
meliputi gaji, kehidupan pribadi, kualitas supervisi, kondisi kerja, jaminan kerja, hubungan antar pribadi, kebijaksanaan dan administrasi perusahaan. Faktor-faktor intrinsik yang berharga pada motivation pekerjaan mencakup keberhasilan, pengakuan, pekerjaan yang menantang, peningkatan dan pertumbuhan dalam pekerjaan.

Uno (2011) menyatakan bahwa fungsi motivasi bagi manusia adalah sebagai motor penggerak bagi manusia, ibarat bahan bakar pada kendaraan, menentukan arah perbuatan, yakni ke arah perwujudan tujuan atau cita-cita, mencegah penyelewengan dari jalan yang ditempuh unuk mencapai tujuan, dalam hal ini semakin jelas tujuan, semakin jelas juga bertentangan jalan yang harus ditempuh, menyeleksi perbuatan diri, artinya menentukan perbuatan mana yang harus dilakukan, yang serasiguna mencapai tujuan dengan menyampaikan perbuatan yang tidak bermanfaat bagi tujuan itu.

Berdasarkan latar belakang masalah tersebut maka terdapat faktor-faktor yang memengaruhi motivasi tutor pendidikan nonformal dalam menjalankan tugasnya sebagai tutor. Dilihat dari paparan masalah, hingga saat ini belum ada kajian lebih lanjut mengenai motivasi kerja bagi tutor pendidikan nonformal dalam menjalankan tugasnya sebagai seorang tutor. Penelitian sebelumnya lebih banyak meneliti di pendidikan formal. Sehingga peneliti tertarik untuk meneliti perbedaan motivasi kerja tutor pendidikan nonformal dilihat dari status perkerjaan di Provinsi Bali.

\section{METODE PENELITIAN}

\section{Variabel dan Definisi Operasional}

Variabel bebas pada penelitian ini adalah status pekerjaan. Variabel terikat pada penelitian ini adalah motivasi kerja. Adapun definisi operasional dari kedua variabel tersebut adalah sebagai berikut:

\section{Motivasi kerja}

Motivasi kerja merupakan suatu penggerak atau dorongandorongan yang terdapat dalam diri manusia yang dapat menimbulkan kepuasan atau ketidakpuasan dalam bekerja. Diukur dengan menggunakan skala motivasi kerja.

Status pekerjaan tutor

Status pekerjaan tutor terdiri dari dua jenis yaitu tutor murni dan tutor dengan pekerjaan tambahan. Tutor murni adalah tutor yang memang kesehariaanya bekerja hanya di lembaga pendidikan non formal. Sedangkan tutor dengan pekerjaan tambahan bekerja selain menjadi seorang tutor juga memiliki pekerjaan tambahan diluar dari menjadi tutor contohnya mengajar les atau menjadi guru honor di pendidikan formal.

\section{Responden}

Responden dalam penelitian ini adalah tutor yang ada di Provinsi Bali. Denga kriteria berikut : individu yang bekerja di Pusat Kegiatan Masyarakat (PKBM), individu tinggal di Provinsi Bali, individu yang memiliki ijazah terakhir SMA, individu yang berusia 18 - 60 tahun. Penelitian ini menggunakan teknik sampling nonprobability sampling dengan sampling jenuh melibatkan responden sejumlah 322 tutor.

\section{Tempat Penelitian}

Proses pengambilan sampel dilakukan di Provinsi Bali. Penelitian dilaksanakan pada bulan April 2018

\section{Alat Ukur}

Alat ukur yang digunakan pada penelitian ini adalah skala motivasi kerja. Skala Motivasi kerja dalam penelitian ini disusun oleh peneliti berdasarkan aspek-aspek Motivasi menurut teori dua faktor dari Herzberg yaitu motivation dan hygiens factors. Skala Motivasi kerja tersebut terdiri dari 60 aitem pernyataan yang disusun dalam bentuk skala likert dan aitem-aitem pada kuesioner terdiri dari favorable dan nonfavorable. Terdapat empat alternatif jawaban untuk aitem favorable yaitu setiap jawaban SS (Sangat Setuju) akan diberi nilai 4, S (Setuju) akan diberi nilai 3, TS (Tidak Setuju) akan diberi nilai 2, STS (Sangat Tidak Setuju) akan diberi nilai 1. Sedangkan untuk aitem nonfavorable setiap jawaban SS (Sangat Setuju) akan diberi nilai 1, S (Setuju) akan diberi nilai 2, TS (Tidak Setuju) akan diberi nilai 3, STS (Sangat Tidak Setuju) akan diberi nilai 4. Hasil pengujian reliabilitas pada penelitian ini menggunakan Cronbach Alpha dengan hasil reliabilitas skala motivasi kerja sebesar 0,845 .

\section{Metode Pengumpulan Data}

Pada penelitian ini teknik yang digunakan peneliti untuk mengumpulkan informasi dari subjek adalah dengan menggunakan skala atau kuesioner. Skala yang digunakan adalah sakala motivasi kerja. Peneliti menyebar kuesioner keseluruh tutor yang ada di Provinsi Bali. Jumlah kuesioner yang terisi lengkap dan dapat dianalisis sebanyak 322 kuesioner.

\section{Teknik Analisis Data}

Teknik analisis data yang digunakan dalam penelitian ini adalah uji asumsi penelitian dan uji hipotesis. Uji asumsi penelitian adalah uji normalitas yang dilakukan dengan menggunakan teknik Kolmogorov Smirnov yang terdapat pada program SPSS versi 16.0 for windows. Untuk uji homogenitas dan uji hipotesis menggunakan independent sample t test yang terdapat pada program SPSS versi 16.0 for windows.

\section{HASIL PENELITIAN}

\section{Uji Asumsi Penelitian}

Berdasarkan uji normalitas pada tabel 1 (terlampir). nilai Kolmogorov-Smirnov adalah pada masing-masing indikator motivasi kerja tutor dengan nilai signifikansi sebesar 0,000 sehingga dapat dikatakan bahwa sebaran pada variabel motivasi kerja tutor bersifat normal.

Pada tabel 2 (terlampir), motivasi kerja dengan variabel eksternal memiliki taraf signifikansi sebesar 0,662 ( $>>0,05)$ yang artinya data pada penelitian ini memiliki sebaran data yang homogen. Selanjutnya motivasi kerja dengan variabel internal memiliki taraf signifikansi sebesar 0,889 $(\mathrm{p}>0,05)$ yang artinya data pada penelitian ini memiliki sebaran data yang homogen.

Uji hipotesis dilakukan sejalan dengan tes homogenitas karena memiliki sebaran data yang homogen dan normal, yaitu dengan melihat tabel 2. Tujuan dari uji hipotesis adalah untuk mengetahui apakah terdapat perbedaan rata-rata peningkatan tiap kelompok penelitian. Dapat dilihat nilai signifikansinya 


\section{P. D. YUNIARINI \& NAOMI VEMBRIATI}

sebesar 0,662 dan 0,889 ( $>>0,005)$ dengan demikian Ha ditolak dan Ho diterima, yang artinya tidak terdapat perbedaan motivasi kerja tutor pendidikan nonformal ditinjau dari status pekerjaan di Provinsi Bali.

\section{Analisis Data Tambahan}

Penelitian ini juga memberikan data tambahan dari hasil analisis data yang didapat. Hasil yang diperoleh dari data penelitian dapat dimasukkan kedalam lima kategori.

Dilihat dari tabel 3 (terlampir), dapat disimpulkan bahwa motivasi kerja pada tutor murni maupun tutor dengan pekerjaan tambahan berada pada kategori tinggi dan sangat tinggi. Kategorisasi motivasi kerja tutor murni dengan kategori skor tinggi sejumlah 103 orang 65,6\%. dan kategori skor sangat tinggi sejumlah 54 orang 34,4\%. Kategorisasi motivasi kerja tutor dengan pekerjaan tambahan dengan kategori skor tinggi sejumlah 105 orang $63,6 \%$ dan kategori skor sangat tinggi sejumlah 60 orang $36,4 \%$.

\section{PEMBAHASAN DAN KESIMPULAN}

Penelitian ini merupakan sebuah penelitan komparasi yang bertujuan untuk melihat perbedaan motivasi kerja tutor pendidikan nonformal pada status pekerjaan yaitu tutor murni dan tutor dengan pekerjaan tambahan. Berdasarkan hasil uji hipotesis yang dilakukan, diperoleh nilai signifikansinya sebesar 0,662 dan 0,889 ( $>00,005)$ dengan demikian Ha ditolak dan Ho diterima, yang artinya tidak terdapat perbedaan motivasi kerja tutor pendidikan nonformal ditinjau dari status pekerjaan di Provinsi Bali.

Dari hasil kategorisasi skor motivasi kerja dapat disimpulkan berdasarkan hasil motivasi kerja tutor murni dan tutor dengan pekerjaan tambahan lainnya sudah berada dalam kategori motivasi kerja tinggi dan sangat tinggi sehingga harus tetap dipertahankan.

Salah satu prediktor dalam motivasi kerja adalah gaji (salary). Menurut Wahyuningsih (2011) dalam penelitiannya menunjukkan terdapat perbedaan motivasi kerja guru PNS dan guru non PNS terdapat perbedaan ditinjau dari kepuasan gaji yang diperoleh. Guru PNS lebih termotivasi dalam bekerja dibandingkan dengan guru non PNS. Dari tabel 14 dilihat terdapat perbedaan baik motivasi internal dan motivasi eksternal baik pada tutor murni maupun tutor dengan pekerjaan tambahan. Motivasi eksternal pada seluruh tutor lebih tinggi daripada motivasi internal pada seluruh tutor, jadi gaji sangat berperan dalam peningkatan motivasi kerja tutor.

Hasil uji independent sample t test motivasi kerja tutor dilihat dari indikator motivasi internal dan motivasi eksternal pada tutor baik tutor murni maupun tutor dengan pekerjaan tambahan tidak terdapat perbedaan. Penelitian ini mengungkapkan bahwa tutor di Provinsi Bali sudah memiliki motivasi kerja tinggi. Tidak ada perbedaan antara motivasi kerja tutor murni dan tutor dengan pekerjaan tambahan baik motivasi eksternal (hygiene factors) dan motivasi internal (motivations). Tetapi terdapat perbedaan motivasi eksternal dan motivasi internal pada tutor murni dan tutor dengan pekerjaan tambahan. Baik tutor murni maupun tutor dengan pekerjaan tambahan memiliki motivasi eksternal lebih besar daripada motivasi internal. Hal ini sejalan dengan penelitian yang dilakukan oleh Jasman., Syam., Christanto., \& Mastono (2015) mengatakan bahwa tidak terdapat perbedaan antara motivasi eksternal dan motivasi internal terhadap kinerja guru jika diuji secara parsial. Penelitian ini menunjukkan jika motivasi internal dan motivasi eksternal tidak cukup kuat untuk memengaruhi kinerja guru.

Faktor lain yang menyebabkan tidak terdapat perbedaan dalam motivasi kerja tutor adalah jenis kelamin. Hal ini sependapat dengan penelitian yang dilakukan oleh Amboyo (2015) mengatakan jenis kelamin tidak menyebabkan perbedaan motivasi kerja. Dalam penelitian ini jumlah sampel laki-laki dan perempuan yang diperoleh sama sebanyak masing-masing 161 orang laki-laki dan 161 orang perempuan yang menyebabkan bahwa hasil dari motivasi kerja tutor murni dan tutor dengan pekerjaan lain tidak terdapat perbedaan yang signifikan.

Keterbatasan dalam penelitian ini adalah variabel yang diteliti dalam penelitian ini membedakan status pekerjaan tutor dilihat dari motivasi kerja tutor tinggi, sedang, rendah. Untuk penelitian selanjutnya kedepannya motivasi kerja tutor dapat ditinjau dari pangkat dan golongan serta gaji tutor.

Berdasarkan hasil analisis dan pembahasan yang dilakukan dalam penelitian ini dapat ditarik beberapa kesimpulan yaitu tidak terdapat perbedaan motivasi kerja pada tutor murni dan tutor dengan pekerjaan tambahan lainnya dilihat dari status pekerjaannya dan kategorisasi motivasi kerja tutor tergolong kedalam motivasi kerja yang tinggi. Tidak terdapat perbedaan motivasi internal dari tutor murni dan tutor dengan pekerjaan tambahan. Terdapat perbedaan motivasi eksternal pada tutor murni dan tutor dengan pekerjaan tambahan.

Bagi penelitian selanjutnya diharapkan menambahkan referensi terkait dengan tutor pendidikan nonformal. Selain itu, penelitian selanjutnya diharapkan mencantumkan jenis pekerjaan tambahan lain yang dilakukan oleh tutor dengan pekerjaan tambahan pada kuesioner. Bagi tutor dengan pekerjaan tambahan sebaiknya meningkatkan motivasi kerja internal tidak hanya memperhatikan motivasi kerja eksternal, sehingga motivasi kerja tutor di Provinsi Bali tetap tergolong dalam kategorisasi tinggi. Bagi lembaga pendidikan nonformal, selain memperhatikan motivasi eksternal pada tutor harus juga memperhatikan motivasi internal tutor sehingga motivasi kerja tutor baik tutor murni maupun tutor dengan pekerjaan tambahan tetap memiliki motivasi kerja yang tinggi. Bagi pemerintah, disarankan untuk dapat memperhatikan motivasi kerja internal tutor dan motivasi eksternal tutor sehingga tutor pada pendidikan nonformal akan lebih termotivasi dalam bekerja.

\section{DAFTAR PUSTAKA}

Aamodt, M.G (2010). Industrial/ organizational psychology: An applied approach. Sixth Edition. Belmont: Wadsworth Cencange Learning.

Amboyo, A.F., Syafar, A.W., \& Hasanuddin, B. (2015). Pengaruh kedisiplinan, beban kerja, dan motivasi kerja, terhadap kinerja guru laki-laki dan perempuan pada SMK Negeri 1 
Sigi (Studi Perbandingan). E-Jurnal Katalogis, Vol. 3 No 10. Hal. 185-195.

Dapodik (2017). Data Pokok Pendidik. diunduh dari www.dapodikmas.com.

Departemen Pendidikan Nasional, 2003. Undang-Undang Nomor 20 Tahun 2003, Tentang Sistem Pendidikan Nasional, Jakarta: Departemen Pendidikan Nasional.

Dirjen PAUD dan Dikmas. (2017). Petunjuk teknis kesetaraan paket C. Direktorat pembinaan pendidikan keaksaraa dan kesetaraan.

Jasmin., Syam, Christanto., \& Mastono. (2015). Pengaruh Motivasi Internal dan Eksternal Terhadap Kinerja Guru Bahasa Indonesia. Jurnal Pendidikan dan Pembelajaran Hal. 1-10.

Kamil, M. (2011). Pendidikan Nonformal: Pengembangan melalui pusat kegiatan belajar masyarakat (PKBM) di Indonesia (Sebuah Pembelajaran dari Kominka Jepang). Bandung: Alfabeta.

Nurfarhana, S (2016). Pengaruh Gaji dan Bonus Terhadap Motivasi Kerja Pegawai Ditinjau Dari Aspek Syariah Pada Kantor Dinas Pendidikan Provinsi Sulawesi Selatan. (Skripsi dipublikasikan). Universitas Islam Negeri Alauddin, Makasar.

Raharjo, J.T (2005). Pengembangan model pembelajaran kesetaraan: Unnes Press

Sardiman. (2010). Interaksi dan motivasi belajar mengajar. Jakarta: PT. Raja Grafindo.

Sari, W (2016). Pengaruh Gaji dan Motivasi terhadap Kinerja Guru SMA Swasta Bagan Sinembah, Rokan Hilir, Riau. Jurnal Pendidikan, Vol. XII No.1. Hal 65-81.

Senjawati, R. A. (2015). Motivasi Warga Belajar Dalam Mengikuti Kelompok Belajar Paket C di Pusat Kegiatan Belajar Masyarakat Tunas Bangsa Brebes. Jurnal of Nonformal Education. Vol 3, No 1. Hal 40-46.

Siswanto. (2013). Membangun Motivasi Belajar Pendidikan Nonformal Semarang. Fakultas Ilmu Pendidikan Universitas Semarang. Jurnal Pendidikan Vokasi. Vol 3, No 3. Hal 405-412.

Suhendar, S. (2017). Analisis pengaruh kepemimpinan KYAI, budaya pesantren, dan motivasi kerja guru terhadap mutu pendidikan pesantren di provinsi Banten. Jurnal Penelitian Pendidikan. Vol 34, No. 2. Hal 161-169.

Sutisna, D. F. (2012). Peranan PKBM (Pusat Kegiatan Belajar Masyarakat) dalam Menumbuhkan Minat Baca Warga Belajar. Jurnal Mahasiswa Padjadjaran. Vo 1, No 1. Hal $1-17$.

Syamra, Y (2016). Pengaruh Kompensasi Finansial dan Motivasi Kerja Guru Terhadap Kinerja Guru SMK Negeri Pariwisata di Kota Padang. Journal of Economic and Economic Education. Vol 4, No 2. Hal 258-268.

Uno, H. (2011). Teori Motivasi dan Pengukurannya (Analisis di Bidang Pendidikan). Jakarta: Bumi Aksara.

Wahyuningsih, S (2011). Perbedaan Motivasi Kerja Guru PNS dan Non PNS Dilihat Dari Kepemimpinan, Kepuasan Gaji dan Lingkungan Kerja. Jurnal Managemen Sumber Daya Manusia. Vol 5, No 2. Hal 89-99. 


\section{LAMPIRAN}

Tabel 1

Hasil Uji Normalitas One Sample Kolmogorov-Smirnov

One-Sample Kolmogorov-Smirnov Test

Hygiens Factors

322

2.619

.000

Asymp. Sig. (2-tailed)

a. Test distribution is Normal.

Tabel 2

Hasil Uji Homogenitas Levene Test

\section{Independent Samples Test}

Levene's Test for Equality of Variances

t-test for Equality of Means

95\% Confidence Interval of the Difference

F

.191

.019
Sig.

.662

.889

Tabel. 3

Kategorisasi Skor Motivasi kerja Pada Satatus Pekerjaan Tutor

\begin{tabular}{|c|c|c|c|c|c|}
\hline \multirow[t]{2}{*}{ Rentang } & \multirow[t]{2}{*}{ Kategorisasi Skor } & \multicolumn{2}{|c|}{ Tutor Murni } & \multicolumn{2}{|c|}{ Tutor dengan Pekerjaan Tambahan } \\
\hline & & Jumlah & Persentase & Jumlah & Persentase \\
\hline$\leq 105$ & Sangat Rendah & - & - & - & - \\
\hline $105-135$ & Rendah & - & - & - & - \\
\hline $135-165$ & Sedang & - & - & - & - \\
\hline $165-195$ & Tinggi & 103 & $65,6 \%$ & 105 & $63,6 \%$ \\
\hline 195 & Sangat Tinggi & 54 & $34,4 \%$ & 60 & $36,4 \%$ \\
\hline \multicolumn{2}{|c|}{ Total } & 157 & $100 \%$ & 165 & $100 \%$ \\
\hline
\end{tabular}

